\title{
New records of Verrucariaceae (Ascomycota) from Bulgaria
}

\section{Veselin V. Shivarov}

Institute of Biodiversity and Ecosystem Research, Bulgarian Academy of Sciences, 2 Gagarin St., 1113 Sofia, Bulgaria (e-mail: v.shivarov@abv.bg)

Received 16 July 2013 / Accepted 21 October 2013 / Published 3 November 2013

Shivarov, V.V. 2013. New records of Verrucariaceae (Ascomycota) from Bulgaria. - Mycobiota 3: 11-17. doi: $10.12664 /$ mycobiota.2013.03.02

Abstract. Five lichenized fungi in Verrucariaceae, Hydropunctaria rheitrophila, Thelidium fontigenum, T. zwackhii, Verrucaria aquatilis, and V. elaeina, are reported for the first time from Bulgaria. Detailed descriptions, illustrations, and comments are provided.

Key words: Bulgaria, freshwater lichens, lichenized fungi, Verrucariaceae

\section{Introduction}

A significant number of freshwater lichenized fungi are members of Verrucariaceae. They occur on various substrata, mainly in streams on calcareous or siliceous rocks, in both shady and in well illuminated places. Most of these species are sensitive to pollution and eutrophication (Nascimbene \& Nimis 2006; Nascimbene et al. 2007; Thüs \& Schultz 2008). Some of them are considered to be rare, or are regarded as data deficient, needing further investigation.

In Bulgaria, species from this group were published by Szatala (1929), Popnikolov (1931), Vodenicharov (1962), and Popnikolov \& Zhelezova (1964). A complete catalogue of the lichenized fungi in this country was presented by Mayrhofer et al. (2005). Recent contributions to the Bulgarian freshwater Verrucaria species were made by Krzewicka et al. (2007) and Shivarov \& Stoykov (2013). However, this group remains poorly studied and some widespread taxa have still not been recorded from this country. In this article, five species of Verrucariaceae, collected in Bulgarka Natural Park and Shumen Plateau, are added. One of these species was collected from a terrestrial habitat here, but it has been found as facultative amphibious in other parts of Europe and may occur in this habitat in Bulgaria as well. 


\section{Material \& methods}

The studied specimens are deposited at the Mycological Collection, Institute of Biodiversity and Ecosystem Research, Sofia (SOMF). The identification of the species follows Smith et al. (2009). Ascospore measurements are given in the form: (min-) mean \pm standard deviation $(-\max )$, average spore length/width value. The measurements and illustrations of Thelidium zwackhii were made in $10 \% \mathrm{KOH}$. All other specimens were observed in water. Macrophotographs were taken by means of a Windaus Labortechnik D-38678 dissecting microscope equipped with a Canon PowerShot A630 digital camera. Microphotographs were made under Boeco BM-180/T/SP and digital camera HP Photosmart M517.

\section{Taxonomic descriptions}

Hydropunctaria rheitrophila (Zschacke) Keller, Gueidan \& Thüs, Taxon 58: 194, 2009.

Figs 1a, b

Thallus $70-140 \mu \mathrm{m}$ thick, epilithic, subgelatinous, greyish green to olive green; thalline surface smooth or with sparse to numerous black punctae. Prothallus well-defined, whitish. Cortex 10-18 $\mu \mathrm{m}$ thick, paraplectenchymatous, colourless or with pale yellowish pigment, poorly defined. Photobiont cells 5-9 × 4-7 $\mu \mathrm{m}$, arranged in distinct columns. Medulla illdefined, pale brown, paraplectenchymatous; upper layer with intensely pigmented patches. Exciple colourless or pigmented brown in upper part. Involucrellum well-defined or fused with adjacent black patches. Asci 30-37 × 12-16 $\mu \mathrm{m}$, clavate, 8-spored. Ascospores $(8.6-) 11.2 \pm 1.2(-13.6) \times(5.6-) 6.2 \pm 0.6(-8.6) \mu \mathrm{m}$, average $1 / \mathrm{w} 1.8(\mathrm{n}=25)$. Conidiomata not observed.

Specimens examined: BULGARIA, Balkan Range, Bulgarka Natural Park, Stanchov Han village, on rock in Belitsa River, upper watershed (submerged in water), 19 Jun 2012, V.V. Shivarov (SOMF 28 053, 28 054).

Ecology \& distribution. Widespread species, on long-submerged rocks. Known from Europe, Australia, New Zealand, and North America (Orange 2004).

Comments. This species is easily recognized by having entirely immersed perithecia, a greenish thallus, with easily visible black punctae when wet. The difference between adjacent thalli of Hydropunctaria rheitrophila and Verrucaria aquatilis Mudd can be seen on Fig. 1a.

Thelidium fontigenum A. Massal., Miscell. Lichenol.: 31, 1856.

Figs 1c, d

Thallus immersed or superficial, thin to thick, slightly rimose, sometimes with small dark flecks; white or greyish white; orange-yellow or purple-red patches and fissures often present; pigment $\mathrm{K}+$ violet. Perithecia 110-270 $\mu \mathrm{m}$ diam., immersed to semi-immersed, leaving pits in the substratum. Exciple 150-290 $\mu \mathrm{m}$ diam., dark brown to pale brown; basal part pale brown to colourless. Involucrellum up to $32 \mu \mathrm{m}$ thick, apical or reaching halfway down the exciple, closely appressed or laterally spreading. Ascospores (23.6-)29.2 $\pm 3.9(-35.9) \times(8.9-) 10.7 \pm 1.1(-11.9) \mu \mathrm{m}$, average $1 / \mathrm{w}$ ratio $2.7(\mathrm{n}=25)$, colourless, elongate, 3 -septate. Conidiomata not observed. 

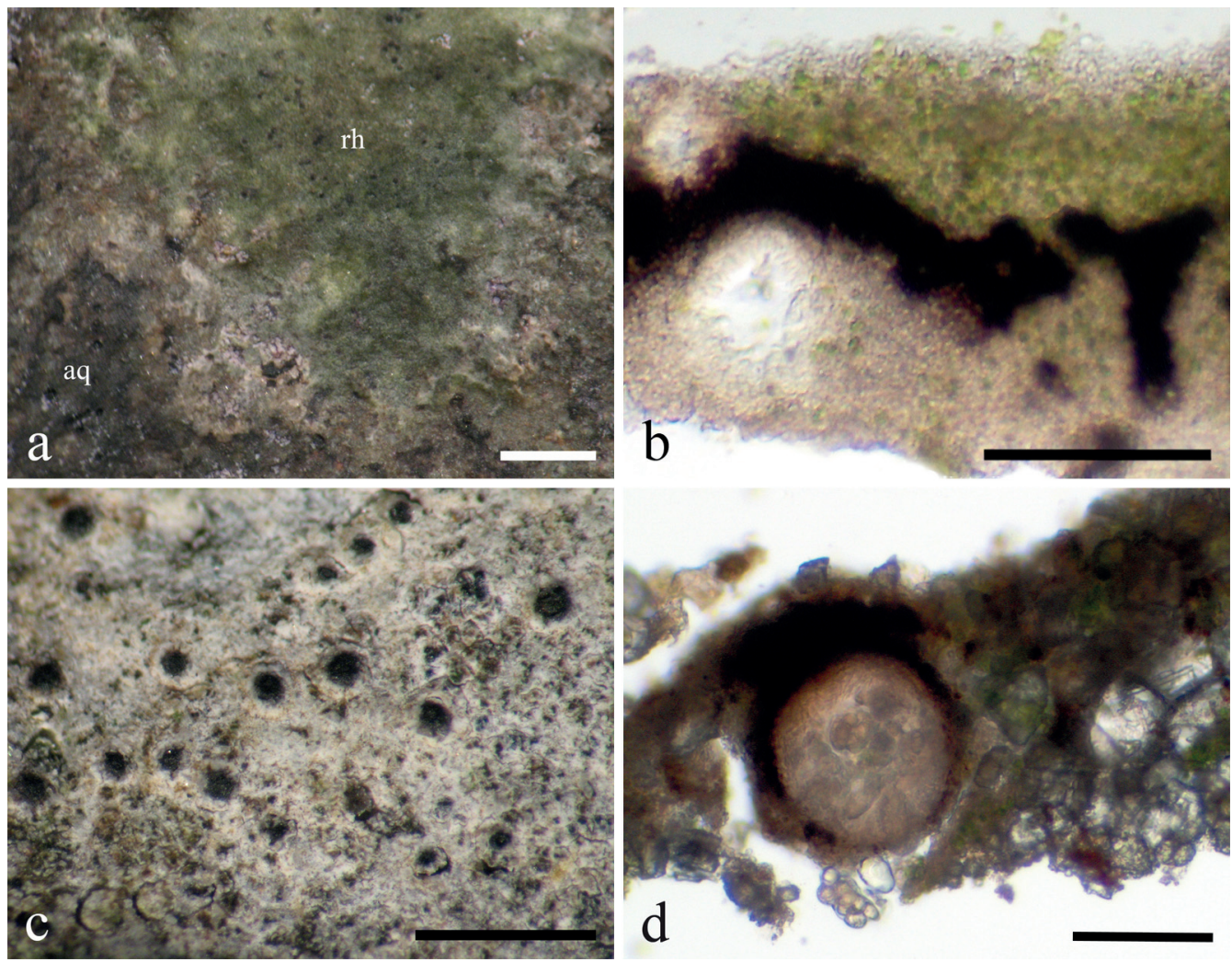

Fig. 1. Thalli and vertical sections of perithecia: a, b-Hydropunctaria rheitrophila (SOMF 28 053); c, d - Thelidium fontigenum (SOMF 28 062). Scales: a, c = 1 mm; b, d = $100 \mu \mathrm{m}$

Specimen examined: BULGARIA, Balkan Range, Bulgarka Natural Park, damp calcareous rocks near the road along Souhata Reka, 21 Jun 2012, V.V. Shivarov (SOMF 28 062).

Ecology \& distribution. Occurs on damp alkaline substrata (limestone, lime-containing sandstone, on silt-impregnated wood, also on mica schist). Widely distributed from low mountain range to (sub-) alpine regions. Reported from Europe and North America (Liška et al. 2008; Thüs \& Nascimbene 2008; Orange 2009).

Comments. Differs from other members of the genus by the presence of $\mathrm{K}+$ violet pigment in the thallus. Thelidium incavatum Mudd is similar in outer appearance and spore septation but differs by having large immersed perithecia, 400-630 $\mu \mathrm{m}$ in diameter, and larger ascospores, 40-58 ×9-16 $\mu \mathrm{m}$. 
Thelidium zwackhii (Hepp) A. Massal., Framm. Lichenogr.: 16, 1855.

Figs 2a, b

Thallus superficial, thin, grey-green, dark green, whitish to brownish, forming flecks or a continuous or slightly cracked crust, formed of goniocyst-like units with brown pigment on their surfaces. Perithecia 140-250 $\mu \mathrm{m}$ diam., half-immersed to almost sessile on the thallus. Exciple 180-260 $\mu \mathrm{m}$ diam., upper half brown, below colourless. Involucrellum absent. Ascospores (23.7-) $29.7 \pm 2.6(-32.2) \times(10.6-) 11.5 \pm 0.7(-13.0) \mu \mathrm{m}$, average $1 / \mathrm{w}$ ratio $2.6(\mathrm{n}=25)$, 3-septate colourless. Conidiomata not observed.

Specimen examined: BULGARIA, Balkan Range, Bulgarka Natural Park, along the road above Plachkovtsi, Stoevska River, on sandstone rock in water, 22 Jun 2012, V.V. Shivarov (SOMF 28 056).

Additional specimen examined: SWITZERLAND, Zürich, on sandstone, Oct 1877, G. Winter (BP 77 923).

Ecology and distribution. On a variety of substrata (limestone, siliceous rock, sandstone, chalk, hardwood, and soil) in amphibious and terrestrial sites, as a pioneer species. Known from Europe, Eurasia, and North America (Harris \& Ladd 2005; Orange 2009; Urbanavichus \& Andreev 2010).

Comments. It can be easily distinguished from other members of this genus by the absence of an involucrellum, 3-septate spores, and small sessile perithecia. Thelidium fontigenum differs by the almost immersed perithecia with a thin apical involucrellum, while T. rehmii and T. minutulum possess 1-septate ascospores.

Verrucaria aquatilis Mudd, Man. Brit. Lich.: 285, 1861.

Figs 2c, $d$

Thallus $20-70 \mu \mathrm{m}$ thick, epilithic, blackish, dark brown to dark greenish brown, subgelatinous. Cortex with greenish brown to dull brown pigment, covered by a transparent layer of dead cells. Photobiont cells 8-15 × 6-10 $\mu \mathrm{m}$, uniformly scattered. Medulla 10-20 $\mu \mathrm{m}$ thick, well developed near perithecia, or absent, paraplectenchymatous, unpigmented, or pale brown; sometimes with brown spots, but not forming a well-defined basal layer. Perithecia 100-240 $\mu \mathrm{m}$ diam., forming low to moderate conical-hemispherical projections, half or three-quarter immersed. Involucrellum 200-400 $\mu \mathrm{m}$ wide, dark brown, conical, reaching base of thallus. Exciple 130-180 $\mu \mathrm{m}$, globose, colourless. Ascospores (5.9-)6.6 $\pm 0.4(-7.4) \times(4.5-) 5.4 \pm 0.3(-6.0) \mu \mathrm{m}$, average $1 / \mathrm{w}$ ratio $1.2(\mathrm{n}=25)$, globose to broadly ellipsoid, simple, colourless, without perispore. Conidiomata not observed.

Specimen examined: BULGARIA, Balkan Range, Bulgarka Natural Park, immersed in Belitsa River, on sedimentary limestone, 19 Jun 2012, V.V. Shivarov (SOMF 28 040).

Ecology and distribution. On long-submerged calcareous or siliceous rocks; widespread in the world (Orange 2004; Krzewicka 2012).

Comments. Verrucaria aquatilis differs from other freshwater species of Verrucaria by having small perithecia and very small, globose to broadly ellipsoid ascospores. The examined specimen was collected from submerged rock, growing together with Verrucaria elaeomelaena (A. Massal.) Arnold, Hydropunctaria rheitrophila (Zschacke) Keller et al., and a freshwater red alga, Hildenbrandia sp. 

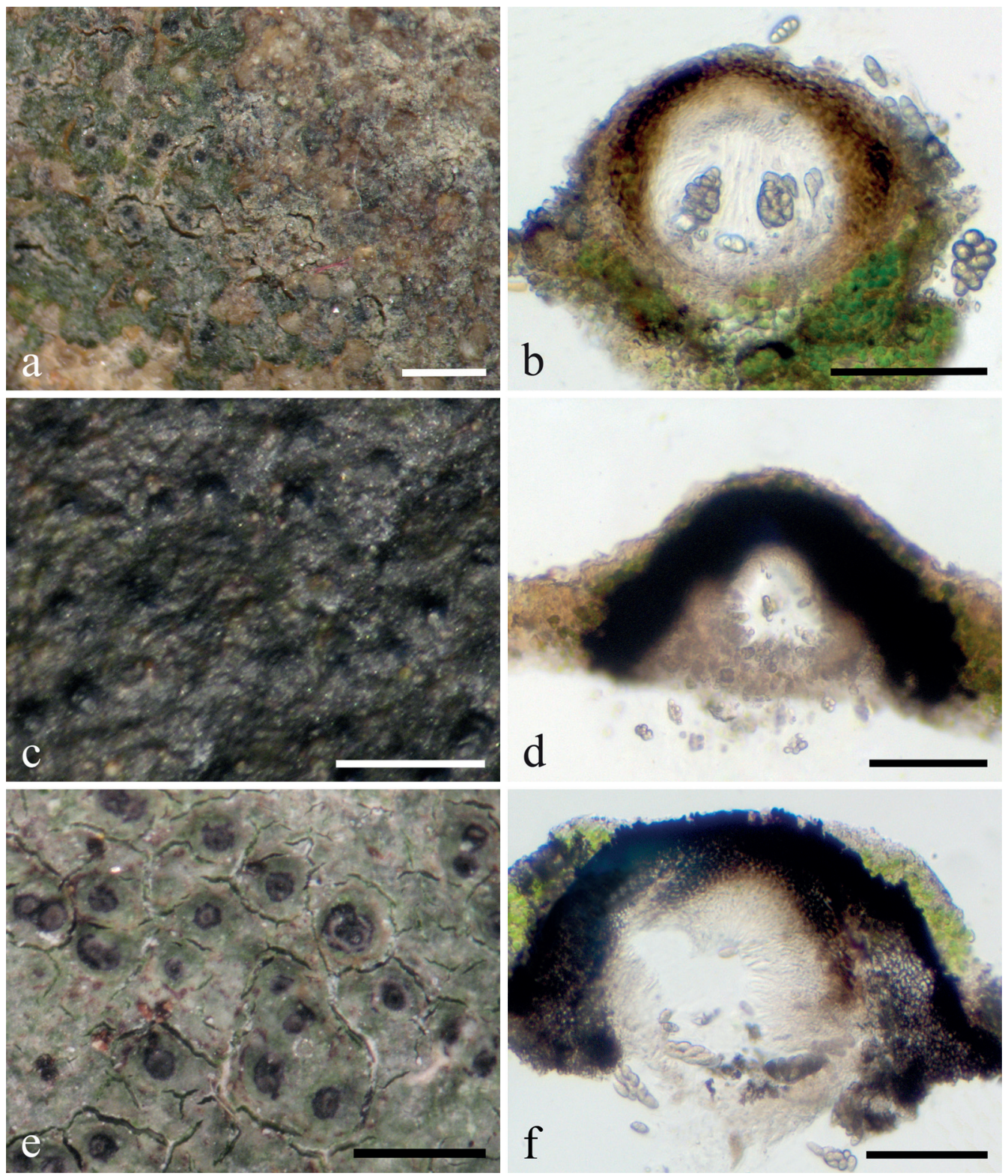

Fig. 2. Thalli and vertical sections of perithecia: a, b - Thelidium zwackhii (SOMF 28 056); c, $\mathbf{d}$-Verrucaria aquatilis (SOMF 28 040); e, $\mathrm{f}$ - Verrucaria elaeina (SOMF 28 033). Scales: a, c, e = $1 \mathrm{~mm}$; b, d, f = $100 \mu \mathrm{m}$ 
Verrucaria elaeina Borrer, in Hooker, Engl. Bot. Suppl. 1: text to Plate 2623 (Fig. 2), 1830.

Thallus 40-100 $\mu \mathrm{m}$ thick, epilithic, non-gelatinous, light grey-green to pale brownish green, intensely green coloured in wet condition, rimose. Prothallus white, or inconspicuous. Cortex 10-20 $\mu \mathrm{m}$ thick, ill-defined, comprising only an alga-free zone. Algal layer 40-60 $\mu \mathrm{m}$ thick, paraplectenchymatous. Photobiont cells $6-10 \times 4-6 \mu \mathrm{m}$. Medulla absent or weakly developed, colourless without black basal layer. Perithecia $210-410 \mu \mathrm{m}$ in diam., one-quarter to three-quarters immersed, sometimes covered with thallus to near the apex; ostiolar region surrounded by a whitish ring-like area. Involucrellum 340-510 $\mu \mathrm{m}$ wide, well-developed, black to dark brown, weakly coloured in basal parts; conical-hemispherical to conical, usually more or less spreading from the exciple below. Exciple 180-260 $\mu \mathrm{m}$ wide, colourless to dilute brown in ostiolar region. Ascospores (15.4-) $18.9 \pm 1.4(-21.4) \times(6.5-) 7.4 \pm 0.5(-8.3) \mu \mathrm{m}, 1 / \mathrm{w}$ ratio usually c. 2.5 $(\mathrm{n}=25)$, simple, colourless, narrowly ellipsoid to oblong-ellipsoid, without perispore. Conidiomata not observed.

Specimens examined: BULGARIA: Northeast Bulgaria, Shoumen Plateau, near to Zandana Cave, on calcareous rock (fragment of monument) in shady humid place, 5 Aug 2012, V.V. Shivarov (SOMF 28 023, 28 033, 28 039, 28 050).

Ecology and distribution. In shady humid localities (facultatively amphibious). Known from watercourses submerged only sporadically, never permanently. Growing on a variety of substrata, such as limestone, sandstone, mortar and on some man-made substrata like concrete, bricks, derelict buildings, and others. Verrucaria elaeina is reported from Europe (Krzewicka 2012).

Comments. Verrucaria elaeina is characterised by a light grey-green thallus, growing in shady places. In the examined specimens, a characteristic whitish ring surrounding the ostiolar region was easily observed under the dissecting microscope. It is distinguished from Verrucaria praetermissa (Trevisan) Anzi by more prominent perithecia and a less widely spreading involucrellum (for more details about the morphology and differences between these two species see Orange 2000). Bulgarian specimens of $V$. submersella Servit differ by having larger ascospores $20-26 \times 9-14 \mu \mathrm{m}$ and the involucrellum reaching only halfway down the exciple.

Acknowledgments. The author thanks Alan Orange (Department of Biodiversity and Systematic Biology, National Museum of Wales) for checking the English and valuable suggestions, and the referees for constructive comments. He is also grateful to Dr László Lőkös (Department of Botany, Hungarian Natural History Museum, Hungary) for the generous help and assistance received during his visit to the Lichen Collection (BP). Part of this study is financially supported by SYNTHESYS program, project HU-TAF-2782 "Taxonomic study of Verrucariaceae (lichenized fungi) in Bulgaria". 


\section{References}

Harris, R.C. \& Ladd, D. 2005. Ozark lichens; Enumerating the lichens of the Ozark Highlands of Arkansas, Kansas, Illinois, Missouri, and Oklahoma. Prepared for the $14^{\text {th }}$ Tuckerman Lichen Workshop, Eureka Springs, Arkansas, October 2005. Publisher not indicated. Available at http://sweetgum.nybg.org/ ozarklichens/biblio_detail.php?irn=132967.

Krzewicka, B. 2012. A revision of Verrucaria s.l. (Verrucariaceae) in Poland. - Polish Botanical Studies 27: 1-143.

Krzewicka, B., Stoykov D.Y. \& Nowak, J. 2007. New and noteworthy species of Verrucaria from Bulgaria. - Mycologia Balcanica 4: 131-134.

Liška, J., Palice, Z. \& Slavíková, Š. 2008. Checklist and red list of lichens of the Czech Republic. - Preslia 80: $151-182$

Mayrhofer, H., Denchev, C.M., Stoykov, D.Y. \& Nikolova, S.O. 2005. Catalogue of the lichenized and lichenicolous fungi in Bulgaria. - Mycologia Balcanica 2: 3-61.

Nascimbene, J. \& Nimis, P.L. 2006. Freshwater lichens of the Italian Alps: a review. - Annales de Limnologie 42: $27-32$.

Nascimbene, J., Thüs, H., Marini, L. \& Nimis, P.L. 2007. Freshwater lichens in springs of the eastern Italian Alps: floristics, ecology and potential for bioindication. - Annales de Limnologie 43: 285-292.

Orange, A. 2000. Verrucaria elaeina, a misunderstood European lichen. - Lichenologist 32: 411-422. doi: 10.1006/lich.2000.0283

Orange, A. 2004. A remarkable new freshwater Verrucaria from Europe. - Lichenologist 36: 349-354. doi: 10.1017/S002428290401446X

Orange, A. 2009. Thelidium A. Massal. - In: C.W. Smith, A. Aptroot, B.J. Coppins, A. Fletcher, O.L. Gilbert, P.W. James \& P.A. Wolseley (eds). The lichens of Great Britain and Ireland. $2^{\text {nd }} \mathrm{edn}$. Pp. 879-883. The British Lichen Society, London.

Popnikolov, A. 1931. [Lichen flora of Mt Vitosha]. - Godishnik na Sofiiskiya Universitet, FizikoMatematicheski Fakultet 27(3): 29-74. (In Bulgarian)

Popnikolov, A. \& Zhelezova, B. 1964. [Flora of Bulgaria. Lichens]. Narodna Prosveta, Sofia. (In Bulgarian) Shivarov, V.V. \& Stoykov, D.Y. 2013. New records of pyrenocarpous lichenized fungi from Bulgaria. Mycotaxon 121[2012]: 133-138. doi: 10.5248/121.133

Smith, C.W., Aptroot, A., Coppins, B.J., Fletcher, A., Gilbert, O.L., James, P.W. \& Wolseley, P.A. (eds) 2009. The lichens of Great Britain and Ireland. $2^{\text {nd }}$ edn. Pp. 10-15. The British Lichen Society, London. Szatala, Ö. 1929. Beiträge zur Flechtenflora von Bulgarien. I. - Magyar Botanikai Lapok 28: 82-99.

Thüs, H. \& Nascimbene, J. 2008. Contributions toward a new taxonomy of Central European freshwater species of the lichen genus Thelidium (Verrucariales, Ascomycota). - Lichenologist 40: 499-521. doi: $10.1017 /$ S0024282908007603

Thüs, H. \& Schultz, M. 2008[2009]. Freshwater flora of Central Europe. Vol. 21/1, Fungi, Part 1, Lichenes. Spektrum, Heidelberg.

Urbanavichus, G. \& Andreev, M. 2010. A checklist of lichen flora of Russia. Nauka, St Petersburg.

Vodenicharov, D. 1962. [Hydrobotanical studies of Ourdin Circus (Northwest Rila Mts)]. - Godishnik na Sofiiskiya Universitet, Biologo-Geologo-Geografski Fakultet 54-55(1)[1959-1961]: 139-211. (In Bulgarian) 